\title{
Management of Xanthomonas Leaf Blight of Onion with Bacteriophages and a Plant Activator
}

\author{
Jillian M. Lang, Department of Bioagricultural Sciences and Pest Management, Colorado State University, Fort \\ Collins 80523-1177; David H. Gent, U.S. Department of Agriculture-Agricultural Research Service, National For- \\ age Seed Production Research Center, Department of Botany and Plant Pathology, Oregon State University, Corvallis \\ 97331-8539; and Howard F. Schwartz, Department of Bioagricultural Sciences and Pest Management, Colorado \\ State University, Fort Collins 80523-1177
}

\begin{abstract}
Lang, J. M., Gent, D. H., and Schwartz, H. F. 2007. Management of Xanthomonas leaf blight of onion with bacteriophages and a plant activator. Plant Dis. 91:871-878.

Xanthomonas leaf blight of onion (Allium cepa), caused by Xanthomonas axonopodis pv. allii, continues to be a challenging and yield-threatening disease in Colorado and other regions of onion production worldwide. Studies were conducted to develop management strategies for this disease that are equally effective and more sustainable than the current practices of making multiple applications of copper bactericides. Mixtures of bacteriophages and the plant defense activator, acibenzolar- $S$-methyl, were evaluated under field and greenhouse conditions for their abilities to reduce Xanthomonas leaf blight severity. Bacteriophage populations in the phyllosphere of onion were monitored over time. Bacteriophage populations persisted on onion leaves for at least 72 to $96 \mathrm{~h}$ under field and greenhouse conditions, respectively. Under field conditions at one location, biweekly or weekly applications of bacteriophages reduced disease severity by 26 to $50 \%$, which was equal to or better than weekly applications of copper hydroxide plus mancozeb. Acibenzolar- $S$-methyl also successfully reduced disease severity by up to $50 \%$ when used alone preventatively or followed by biweekly bacteriophage applications. Reductions in disease severity generally were not associated with improvements in onion bulb size or yield. Integration of bacteriophage mixtures with acibenzolar- $S$-methyl appears to be a promising strategy for managing Xanthomonas leaf blight of onion, and could reduce grower reliance on conventional copper bactericide applied with ethylenebisdithiocarbamate fungicides.
\end{abstract}

Additional keywords: bacterial blight, biological control, integrated pest management, systemic acquired resistance

Xanthomonas leaf blight of onion (Allium cepa), caused by Xanthomonas axonopodis pv. allii, is a challenging disease to manage in Colorado and certain other regions of onion production $(1,12,27)$. Alvarez et al. (1) first described the disease in Hawaii in 1978, and reported symptoms that included stunting of plants, tip dieback, and lenticular-shaped, water-soaked lesions that elongated into chlorotic streaks on the flat sides of older leaves. The premature death of leaves results in a reduction of bulb size at harvest, but a bulb rot has not been reported.

Corresponding author: H. F. Schwartz

E-mail: Howard.Schwartz@ColoState.edu

The use of trade, firm, or corporation names in this publication is for the information and convenience of the reader. Such use does not constitute an official endorsement or approval by the United States Department of Agriculture or the Agricultural Research Service of any product or service to the exclusion of others that may be suitable.

Accepted for publication 5 March 2007.

doi:10.1094/PDIS-91-7-0871

(C) 2007 The American Phytopathological Society
Xanthomonas leaf blight of onion has since been reported in Barbados (26), the continental United States $(17,22,30,32)$, Japan (19), Réunion Island (27,28), and South Africa (35). X. axonopodis pv. allii is pathogenic to onion and certain other Allium species $(12,19,27)$. The pathogen can multiply in leaves of common bean (Phaseolus vulgaris) (12) and survive epiphytically on leguminous plants such as alfalfa (Medicago sativa), chickpea (Cicer arietinum), common bean, lentil (Lens culinaris), and soybean (Glycine max) (9), but disease symptoms on these hosts are rare or do not occur $(12,27)$.

Leaf blight of onion is favored by moderate to high temperatures and wind-driven rain during and after bulb initiation (34), presumably because the bacterium is dispersed by water splashing (29). Aerosolized cells of the pathogen are detectable in the air above onion fields as soon as 2 to 8 weeks after planting (25). X. axonopodis pv. allii is widespread in and near onion fields in Colorado, and may be found in irrigation water, surviving epiphytically on weeds, alternate hosts, and volunteer onions $(8,9)$. Excessive nitrogen fertilization may exacerbate disease severity (10). Contaminated seed may be a less critical in- oculum source for Xanthomonas leaf blight epidemics in Colorado or other semi-arid regions without sprinkler irrigation (10) when pathogen levels are low, than under tropical or subtropical conditions or when overhead irrigation is used $(28,29)$.

Management of Xanthomonas leaf blight of onion in Colorado has primarily consisted of multiple applications of copper bactericides tank mixed with ethylenebis dithiocarbamate (EBDC) fungicides (33). Repeated use of copper can lead to the pathogen developing resistance $(4,36)$, and may have harmful effects on humans and the surrounding ecosystem (16). O'Garro and Paulraj (24) reported that sprays of copper-based bactericides were generally ineffective in tropical production, and suggested copper insensitivity contributed to poor efficacy (25). Copper insensitivity has not been documented in strains of $X$. axonopodis pv. allii prevalent in temperate regions (12), but could appear with continued reliance upon copper bactericides for disease management. Management of Xanthomonas leaf blight may be possible without conventional bactericides by use of biological control and systemic acquired resistance (11).

Bacteriophages represent innovative biological control agents because they are highly specific viruses with extreme host specificity, unique ultra-microscopic nature, and ability to self-replicate within host cells (20). Bacteriophages have been successfully used for managing several plant diseases since the submission and acceptance of a bacteriophage patent for plant disease control (18). Biological control of Xanthomonas leaf blight with bacteriophages may reduce or replace copper bactericides.

Flaherty et al. (7) used foliar applications of a host-mutant (H-mutant) mixture of bacteriophages to manage bacterial spot of tomato (caused by Xanthomonas axonopodis pv. vesicatoria) in the field and greenhouse. The bacteriophage mixture, developed from diverse host bacterial strains (AgriPhage, OmniLytics, Salt Lake City, UT), improved disease suppression and total weight of extra-large fruit as compared to copper bactericides. Flaherty et al. (6) reported 50 and $75 \%$ reductions in the incidence and severity, respectively, 
of geranium bacterial blight (caused by Xanthomonas horotum pv. pelargonii), relative to control plants, by daily applications of the bacteriophages beginning 6 weeks after initial treatment. Balogh et al. (3) developed formulations to increase bacteriophage longevity on plant foliage, including a successful and simple powdered skim milk-sucrose solution.

Another alternative strategy for managing onion Xanthomonas leaf blight is using systemic acquired resistance (SAR) inducers or plant activators like acibenzolar- $S$ methyl (Actigard 50WG, Syngenta Crop Protection, Greensboro, NC). Acibenzolar$S$-methyl is a broad-spectrum product that could be utilized for protection against a variety of bacterial, fungal, and viral pathogens and has been proven effective in managing bacterial wilt on tomato (2), bacterial spot and speck on tomato (21), and Xanthomonas leaf blight of onion (11). Acibenzolar- $S$-methyl is a structural ana$\log$ of salicylic acid, one of the primary signaling compounds in SAR. Acibenzolar- $S$-methyl has minimal impact on beneficial insects and exhibits a unique mode of action making resistance development unlikely. However, there are some concerns in using a plant activator for disease management because of the potential for phytotoxicity and yield reduction $(5,11)$.

Biological control of plant pathogens is an important research area due to the increased demand for sustainable agricultural practices and for reduction of reliance on conventional chemical disease management. Combining bacteriophages with a plant activator may be an effective management strategy for Xanthomonas leaf blight of onion $(11,23)$, but no study has reported using bacteriophages to manage this disease. Therefore, the goals of this work were to better understand bacteriophage ecology in the onion phyllosphere and to develop and test the efficiency of an alternative management program for Xanthomonas leaf blight of onion using bacteriophage mixtures and acibenzolar- $S$ methyl.

\section{MATERIALS AND METHODS}

Bacterial strains and culture. A rifampicin mutant of $X$. axonopodis pv. allii strain 0177 (ATCC 508) was generated as described previously $(12,37)$, and is referred to as R-O177. Strain O177 was the most recently isolated strain in Colorado. This is also the $X$. axonopodis pv. allii strain studied most extensively. Strain R$\mathrm{O} 177$ is resistant to greater than $200 \mu \mathrm{g} / \mathrm{ml}$ rifampicin, but selection was routinely performed on nutrient agar amended with $25 \mu \mathrm{g} / \mathrm{ml}$ of rifampicin. Other strains of $X$. axonopodis pv. allii were cultured on nutrient agar lacking antibiotic during incubation at $29^{\circ} \mathrm{C}$. To prepare inoculum, loopsful of bacteria were streaked onto rifampicin-amended nutrient agar (strain
R-O177) or yeast dextrose calcium carbonate medium $(\mathrm{O} 177)$ before incubating culture plates at $29^{\circ} \mathrm{C}$ for $72 \mathrm{~h}$ in the dark. Cells were harvested from plates by flooding with sterile magnesium phosphate buffer (0.01 M magnesium sulfate and 0.01 $\mathrm{M}$ potassium phosphate, $\mathrm{pH}$ 7.2) or sterile water and gently scraping the plates with a small, flame-sterilized spatula. The buffer was prepared from magnesium sulfate formulated as $\mathrm{MgSO}_{4} \cdot 7 \mathrm{H}_{2} \mathrm{O}$ and potassium phosphate derived from a mixture of both $\mathrm{K}_{2} \mathrm{HPO}_{4}$ and $\mathrm{KH}_{2} \mathrm{PO}_{4}$. The cell suspension was adjusted to $10^{8} \mathrm{CFU} / \mathrm{ml}$ spectrophotometrically $\left(\mathrm{OD}_{600}=0.12\right)$ before adjustment to the desired concentration for an experiment. All bacterial strains were preserved in $15 \%$ nutrient glycerol broth at $-80^{\circ} \mathrm{C}$ for long-term storage.

Bacteriophage mixture. A bacteriophage mixture (referred to as Agriphage) was developed by OmniLytics (Salt Lake City, UT) from a collection of strains of $X$. axonopodis pv. allii that represent each of the five rep-PCR groups reported by Gent et al. (12), and the known genetic and geographic diversity of the pathogen to avoid resistance and variable susceptibility to bacteriophages. Strain O177 was included in the development of this mixture.

Survival of bacteriophage populations in the field. Bacteriophage populations were assessed twice (once each in experiments 1 and 2) during the 2004 field season at the Colorado State University Agricultural Research, Development and Education Center (ARDEC) near Fort Collins, CO. Plants used for monitoring bacteriophage populations were both treated biweekly with a bacteriophage mixture at $10^{8}$ plaque-forming units (pfu)/ml in 114 liters of water per hectare amended with $0.5 \%$ sucrose and $0.75 \%$ powdered skim milk (3) and then sampled at dawn. Plants were approximately 5 months old and had been treated with the bacteriophage mixture eight times prior to sampling. Immediately following early morning application, four plants were selected arbitrarily from each plot. Single outer and inner leaves were removed from each plant and placed into separate resealable bags using latex gloves that were sterilized with $70 \%$ ethanol after handling each plant. Tissue samples were immediately transported to the laboratory to recover bacteriophages. Each tared bag of tissue was weighed before adding $100 \mathrm{ml}$ of sterile magnesium phosphate buffer. Bags were resealed, placed into small plastic bins, and shaken vigorously on a rotary shaker at 250 oscillations/min for $30 \mathrm{~min}$ at room temperature (approximately $22^{\circ} \mathrm{C}$ ).

The rinsate was serially diluted, and a $100-\mu \mathrm{l}$ aliquot was added to $4.5 \mathrm{ml}$ of molten nutrient agar and $500 \mu \mathrm{l}$ of a $10^{9}$ $\mathrm{CFU} / \mathrm{ml}$ suspension of $X$. axonopodis pv. allii strain R-O177. The mixture was combined in a sterile glass test tube and then overlaid onto a plate of nutrient agar amended with $25 \mathrm{mg} / \mathrm{ml}$ rifampicin and 50 $\mathrm{mg} / \mathrm{ml}$ cycloheximide. All antibiotics were purchased from Sigma-Aldrich Chemical Company (St. Louis, MO). Plates were then incubated for $24 \mathrm{~h}$ at $29^{\circ} \mathrm{C}$ before enumerating plaques. This same procedure was used to monitor bacteriophage survival at $12,24,48$, and $72 \mathrm{~h}$ after application of the bacteriophage mixture.

Survival of bacteriophage populations in the greenhouse. Three greenhouse experiments $(1,2,3)$ were conducted at the Colorado State University Plant Growth Facilities, Fort Collins. Plants of the Xanthomonas leaf blight susceptible onion cultivar Vantage were grown under an approximately $24^{\circ} \mathrm{C} / 20^{\circ} \mathrm{C}$ day/night temperature cycle and 14-h photoperiod, with approximately $2 \mathrm{~h}$ of supplemental incandescent lighting for 8 to 10 weeks in MetroMix 200 potting soil (Grace Sierra Horticultural Products Company, Milpitas, CA). Plants were watered and fertilized weekly, and then thinned to three plants per pot, for a total of 48 plants in each trial. The bacteriophage mixture amended with sucrose and powdered skim milk was sprayed on plants at about $10^{8} \mathrm{pfu} / \mathrm{ml}$ in water with a handheld atomizer until just before runoff. One set of 48 plants was inoculated with $10^{7} \mathrm{CFU} / \mathrm{ml} \mathrm{X}$. axonopodis pv. allii strain $\mathrm{O} 177$ to observe the effects that host cells have on bacteriophage populations. Bacteriophage populations were quantified at $4,12,24,48,72$, and $96 \mathrm{~h}$ after inoculation as described above.

Xanthomonas leaf blight field studies. Experiments were conducted in 2003 and 2004 to evaluate a bacteriophage biological control program under field conditions. In 2003, plots were established by directly seeding onions in plots at the Irrigation Research Foundation (IRF) near Yuma, CO in a Haxtun, sandy loam soil and at the Arkansas Valley Research Center (AVRC) near Rocky Ford, CO in a Rocky Ford silty clay loam soil. In 2004, plots were established at AVRC and at ARDEC in a Fort Collins silty loam. Cultivar Vantage was used at Yuma and Fort Collins. Plots were $0.76 \mathrm{~m}$ wide by $7.62 \mathrm{~m}$ in length, and seeds or transplants were planted approximately $3 \mathrm{~cm}$ apart. The field was irrigated by center pivot two to three times per week at Yuma and by furrow irrigation once to twice per week at Fort Collins. At Rocky Ford, the Xanthomonas leaf blight susceptible cultivar X202 was used in 2003 and 2004. Plots were $1.00 \mathrm{~m}$ wide by $7.62 \mathrm{~m}$ in length, and seeds were planted approximately $3 \mathrm{~cm}$ apart. Plots were furrowirrigated every 7 to 10 days, as needed. At all locations, treatments were applied in 94.6 liters of water per hectare using a compressed carbon dioxide backpack sprayer and Teejet 8002 flat-fan nozzles (two per $38-\mathrm{cm}$ boom). Each experiment was a randomized complete block design with four replications. Hourly temperature and rainfall were collected with a CR-10 
weather station (Campbell Scientific, Inc., Logan, UT) maintained on a mowed grass site at each location (34).

Treatments began 2 weeks before inoculation. Plots were inoculated with 2-dayold cultures of $X$. axonopodis pv. allii strain RO177 at $10^{8} \mathrm{CFU}$ in a solution of water and $0.1 \%$ vol/vol Silwet L-77 nonionic surfactant (Helena Chemical Co., Fresno, CA) to ensure complete coverage of all plants. Plots were inoculated 126 and 142 days after planting at Yuma, 151 and 158 days after planting at Rocky Ford in 2003; and 103 and 121 days after planting at Fort Collins, and 133 days after planting at Rocky Ford in 2004. Rocky Ford required only one inoculation in 2004 due to a more conducive disease environment with high temperatures during July and August (34). Repeated inoculations were applied after evaluating plots post the first inoculation and observing plant response. If disease pressure was not adequate (and environmental conditions were not conducive), inoculations were repeated.

Field evaluation of bacteriophages compared to copper hydroxide-mancozeb and acibenzolar-S-methyl. The ability of the $X$. axonopodis pv. allii bacteriophage mixtures (Agriphage) to reduce the severity of Xanthomonas leaf blight was compared to copper hydroxide-mancozeb (ManKocide, Dupont, Wilmington, DE) and acibenzolar- $S$-methyl (Actigard 50WG). In $2003,1.55 \mathrm{~kg}$ a.i./ha copper hydroxide + $0.50 \mathrm{~kg}$ a.i./ha mancozeb was applied weekly beginning 112 and 136 days after planting at Yuma and Rocky Ford, respectively. Six applications were made at Yuma and five were made at Rocky Ford. Bacteriophages were applied biweekly beginning 112 and 136 days after planting at Yuma and Rocky Ford, respectively, at $10^{8}$ $\mathrm{pfu} / \mathrm{ml}$ in a stabilizing solution of water, $0.25 \%$ sucrose, $0.5 \%$ Casecrete NH-400 (American Casein Company, Burlington, $\mathrm{NJ}$ ), and $0.5 \%$ corn flour as described by Balogh et al. (3). Twelve applications were made at Yuma and 10 at Rocky Ford. Acibenzolar- $S$-methyl was applied at $26.3 \mathrm{~g}$ a.i./ha 112 and 119 days after planting at Yuma and 136 and 143 days after planting at Rocky Ford. In 2004, copper hydroxidemancozeb was applied weekly at the rate described above beginning 122 and 89 days after planting at Rocky Ford and Fort Collins, respectively. Eight applications were made at Rocky Ford and 10 were made at Fort Collins. Bacteriophages were applied biweekly at the rate above beginning 122 and 89 days after planting at Rocky Ford and Fort Collins, respectively. Fifteen applications were made at Rocky Ford and 19 applications were made at Fort Collins. Acibenzolar-S-methyl was applied at $26.3 \mathrm{~g}$ a.i./ha 122 and 129 days after planting at Rocky Ford and 89 and 96 days after planting at Fort Collins.

Evaluation of application interval. To determine the most effective interval for bacteriophage applications, five treatments of the same bacteriophage titer $\left(10^{8}\right.$ $\mathrm{pfu} / \mathrm{ml})$ were applied at varying time intervals as follows: 3 - to 4-day interval (16 to 19 total applications); 7-day interval (8 to 10 total applications); or 14-day interval (5 to 6 total applications). For comparison, 8 to 10 weekly applications of $1.55 \mathrm{~kg}$ a.i./ha copper hydroxide $+0.50 \mathrm{~kg}$ a.i./ha mancozeb were also included. All treatments were applied beginning 122 and 89 days after planting at Rocky Ford and Fort Collins, respectively. All bacteriophage treatments were applied in a stabilizing solution of water, $0.5 \%$ sucrose, and $0.75 \%$ powdered nonfat skim milk (3). The study was replicated over location at Rocky Ford and Fort Collins in 2004.

Evaluation of bacteriophage titer. To determine the most effective concentration of bacteriophages to manage Xanthomonas leaf blight, treatments of varying bacteriophage titer were applied in 2004 as follows: 16 to 19 biweekly applications of bacteriophages at: $10^{8}, 10^{7}, 10^{6}$, or $10^{5}$ $\mathrm{pfu} / \mathrm{ml}$. For comparison, eight to 10 weekly applications of copper hydroxidemancozeb at $1.55 \mathrm{~kg}$ a.i./ha copper hydroxide $+0.50 \mathrm{~kg}$ a.i./ha mancozeb were included. All treatments were applied beginning 122 and 89 days after planting at Rocky Ford and Fort Collins, respectively. All bacteriophage treatments were applied biweekly in a stabilizing solution of water, $0.5 \%$ sucrose, and $0.75 \%$ powdered nonfat milk (3). The study was replicated over space at Rocky Ford and Fort Collins in 2004.

Disease and yield data collection and analysis. Disease severity was assessed using a modified Horsfall-Barrett scale and converted to a percentage as previously described $(11,15)$ where a score of 0 represented no disease symptoms and 100 represented death of the entire plant, and gradual increases in severity were rated as $4,8,12,16,24,32,40,50,60,75$, and $85 \%$ disease severity. Ten plants were se- lected arbitrarily from each plot at each evaluation time and were assessed for percentage of the leaf area covered with water-soaked, chlorotic, and/or necrotic tissue. The sample size was selected by determining the minimal sample size where estimates of population mean and variance did not vary significantly with additional sampling. Weekly disease severity estimates were used to calculate the relative area under the disease progress curve (RAUDPC) using the formula:

$$
\left\{\sum_{i=1}^{n}\left[\left(x_{i+1}+x_{i}\right) / 2\right]\left(t_{i+1}-t_{i}\right)\right\} /\left(t_{n}-t_{i}\right)
$$

where $x_{i}=$ disease severity at time $t_{i}$.

Yield data were collected by harvesting a 3-m (Fort Collins) or 2.4-m (Rocky Ford) section from one bed of each plot. Bulbs were sorted to market class (i.e., colossal, jumbo, and medium) (31). Yield data were not collected at Yuma due to variable plant stand. Significant differences between means of RAUDPC and yield were determined by analysis of variance (ANOVA) using SAS version 9.1 (SAS Institute, Cary, NC). Comparison of treatment effects was conducted using Fisher's protected least significant difference test $(P \leq 0.05)$.

\section{RESULTS}

Survival of bacteriophage populations. Bacteriophage populations persisted for at least 5 days under greenhouse conditions and 4 days under field conditions, which were the durations of these studies. In experiment 1 under field conditions, populations dropped $1.3 \log$ units $24 \mathrm{~h}$ after application, but then remained stable for the remainder of the study. In experiment 2, the initial population was much lower than in the first experiment. Unlike in experiment 1 , there was drop of $2.1 \mathrm{log}$ units in bacteriophage populations $12 \mathrm{~h}$ after sampling time, but overnight they multiplied $1.7 \log$ units. Populations diminished again by $1.8 \log$ units at the $48-\mathrm{h}$

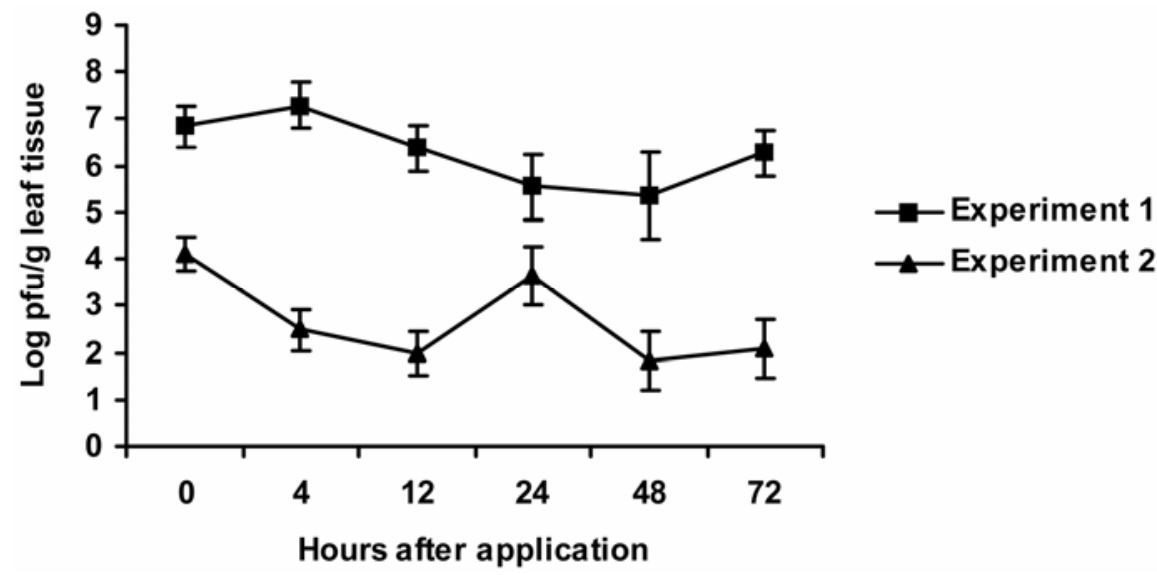

Fig. 1. Recovery of bacteriophage populations surviving on onion leaf foliage under field conditions at Fort Collins, CO, 2004. Experiment 1 took place 12 to 15 August 2004, and experiment 2 took place 6 to 9 September 2004. Data are means of four subsamples from four replications $(n=4) \pm$ standard error of the mean. 
sampling time, then stabilized by the $72-\mathrm{h}$ sampling time (Fig. 1). Experiment and the experiment $\times$ time interaction were significant effects in the mixed model (Table 1), indicating that environmental conditions varied between field trials and the populations responded differently.

Table 1. Type-3 tests of mixed model fixed effects in the analysis of bacteriophage populations surviving on onion leaf foliage under field conditions over time near Fort Collins, CO, 2004

\begin{tabular}{lcccc}
\hline Effect $^{\mathbf{z}}$ & Numerator df & Denominator df & $\boldsymbol{F}$ value & $\boldsymbol{P}$ value \\
\hline Experiment & 1 & 33 & 79.03 & $<0.0001$ \\
Time & 5 & 33 & 2.39 & 0.0588 \\
Experiment $*$ time & 5 & 33 & 2.51 & 0.0496 \\
\hline
\end{tabular}

${ }^{\mathrm{z}}$ A split-plot design was used.
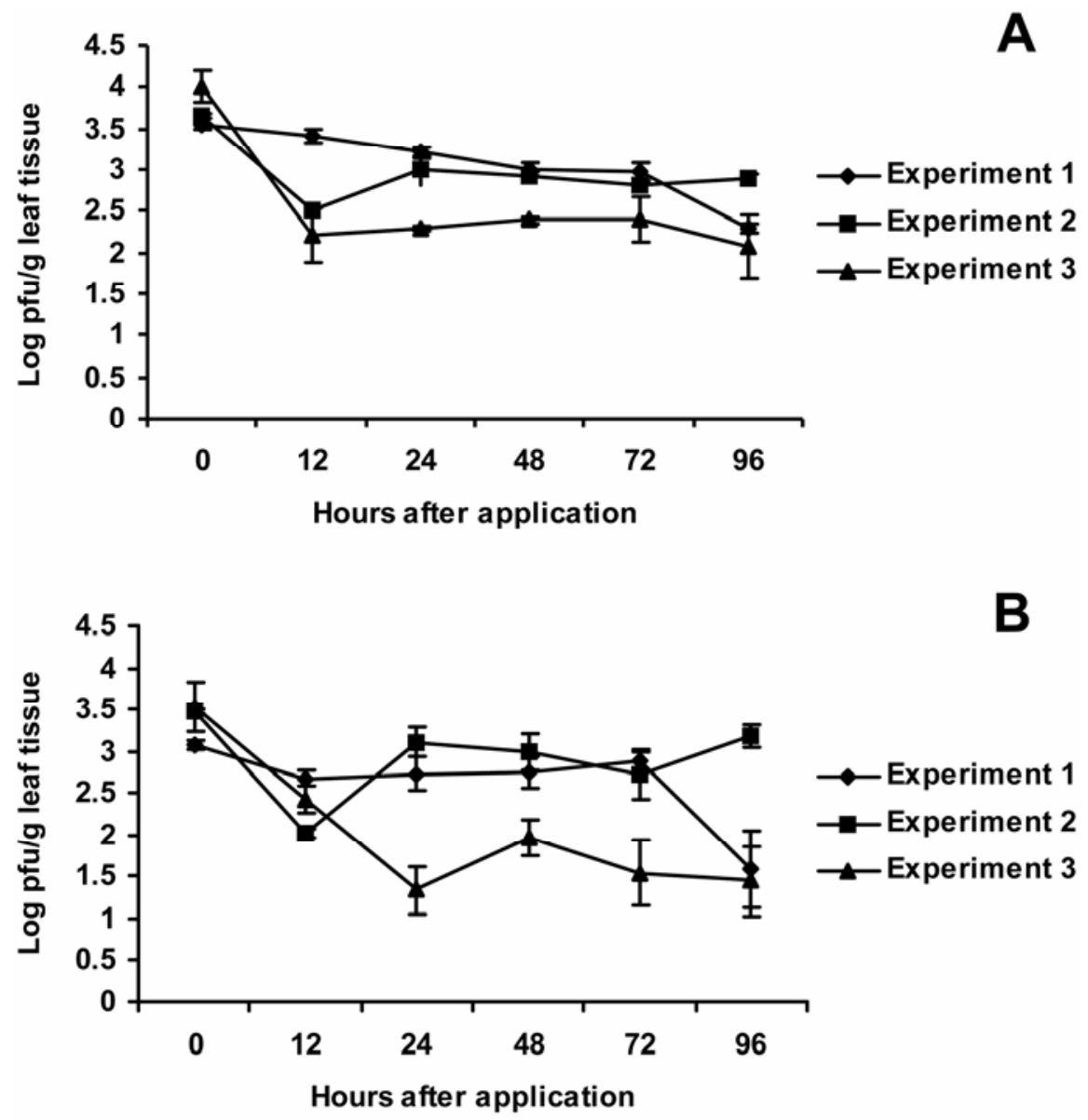

Fig. 2. Recovery of bacteriophage populations surviving on onion leaf foliage in the $\mathbf{A}$, absence or $\mathbf{B}$, presence of host cells under greenhouse conditions, 2004-2005. Experiment 1 took place 11 to 16 November 2004, experiment 2 took place 16 to 20 December 2004, and experiment 3 took place 24 to 28 January 2005. Data are means of three subsamples from four replications $(n=4) \pm$ standard error of the mean.

Table 2. Type-3 tests of mixed model fixed effects in the analysis of bacteriophage populations surviving on onion leaf foliage in the presence or absence of Xanthomonas axonopodis pv. allii over time under greenhouse conditions, Fort Collins, CO, 2004-2005

\begin{tabular}{lcccc}
\hline Effect $^{\mathbf{z}}$ & Numerator df & Denominator df & $\boldsymbol{F}$ value & $\boldsymbol{P}$ value \\
\hline X. axonopodis pv. allii & 1 & 22 & 4.81 & 0.0392 \\
Time & 5 & 22 & 5.40 & 0.0022 \\
$X$. axonopodis pv. allii $*$ time & 5 & 22 & 0.04 & 0.9990 \\
\hline
\end{tabular}

${ }^{\mathrm{z}}$ A split-plot design was used. days at the 24-, 48-, and 72-h sampling times. As expected, bacteriophage populations began to drop by the 96-h sampling time, but during experiments 1 and 3 , study populations were lower in the presence of $X$. axonopodis pv. allii (Fig. 2).

Experiment 2 took place 16 to 20 December 2004, and results differed from experiment 1 . In the presence or absence of $X$. axonopodis pv. allii, bacteriophage populations dropped by the 12-h sampling, and then increased again by the 24-h sampling. Similar to experiment 1 , bacteriophage populations stabilized during the next three sampling times. However, in the presence of $X$. axonopodis pv. allii, bacteriophage populations appeared to increase slightly again by $0.4 \mathrm{log}$ units after $24 \mathrm{~h}$ at the 96-h sampling and remained the same in the absence of $X$. axonopodis pv. allii. In experiment 2 , bacteriophage populations without $X$. axonopodis pv. allii application were slightly lower than those inoculated with the bacterium at the 24-, 48-, and 96-h sampling times.

Experiment 3, conducted 24 to 28 January 2005, had slightly different results from experiments 1 and 2 . In the presence of $X$. axonopodis pv. allii, bacteriophage populations dropped by $2.2 \log$ units at the 24-h sampling time. In the absence of $X$. axonopodis pv. allii, bacteriophage populations dropped $1.8 \log$ units at the 12-h sampling time, and were similar for the remainder of the study. There were significant differences in bacteriophage populations when inoculated with $X$. axonopodis pv. allii. At the 12-h sampling time, populations were higher when inoculated, but for the remainder of the study, populations were very different between inoculated and uninoculated. In all sampling times, bacteriophage populations were lower when plants were inoculated (Fig. 2). The addition of $X$. axonopodis pv. allii was a significant effect in the mixed model (Table 2 ), indicating that bacteriophage populations were affected by the presence of host cells; however, the cells lowered bacteriophage populations. Independent of the presence of $X$. axonopodis pv. allii, bacteriophages persisted on onion foliage under a greenhouse environment for at least $96 \mathrm{~h}$. Replication of the experiment was significant in statistical analysis; therefore, data from all three experiments were not averaged.

Field evaluation of bacteriophage, acibenzolar-S-methyl, and copper hydroxide-mancozeb. Average monthly daily high temperature and cumulative monthly rainfall data were retrieved from the Colorado Climate Center, and were 27 and $30^{\circ} \mathrm{C}$, and 186 and $113 \mathrm{~mm}$ at Yuma and Rocky Ford in 2003, respectively. Average monthly daily high temperatures and cumulative monthly rainfall were 25 and $30^{\circ} \mathrm{C}$, and 181 and $223 \mathrm{~mm}$ at Fort Collins and Rocky Ford in 2004, respectively. 
Bacteriophage titer was inadvertently reduced by application of bacteriophage with compressed carbon dioxide (data not presented). The introduction of carbon dioxide to the bacteriophage solution may have changed the $\mathrm{pH}$ to create a harsh environment not conducive to bacteriophage fitness. However, populations were sustained, as shown by population monitoring studies, and still affected disease severity. In 2003 at Yuma, the RAUDPC was reduced by all treatments compared to the untreated, but treatments were not different from each other (Table 3). Copper hydroxide-mancozeb, bacteriophages alone, bacteriophages with copper hydroxidemancozeb, and bacteriophages with acibenzolar- $S$-methyl reduced disease severity by $31,35,31$, and $50 \%$, respectively. At Rocky Ford, consistent with Yuma results, all treatments reduced Xanthomonas leaf blight compared to the untreated, but treatments were not different from each other. Copper hydroxide-mancozeb, bacteriophages alone, bacteriophages with copper hydroxide-mancozeb, and bacteriophages with acibenzolar- $S$-methyl reduced disease severity by $32,26,32$, and $42 \%$, respectively. Total yield was not affected by any treatment. The bacteriophages alone or with acibenzolar- $S$-methyl decreased the yield of medium-sized bulbs by $51 \%$, while the bacteriophage with acibenzolar- $S$-methyl or with copper hydroxide-mancozeb treatments increased the yield of jumbo-sized bulbs by 29 and $27 \%$, respectively.

In 2004 at Fort Collins, the RAUDPC was reduced by all treatments compared to the untreated. Bacteriophages with acibenzolar- $S$-methyl reduced the RAUDPC by $24 \%$ as compared to copper hydroxide- mancozeb (Table 4). Bulb yield and grade were similar among treatments. At Rocky Ford, the RAUDPC was reduced by all treatments compared to the untreated. Bacteriophages alone suppressed disease as well as copper hydroxide-mancozeb. Bacteriophages with copper hydroxidemancozeb, bacteriophages with acibenzolar- $S$-methyl, and acibenzolar- $S$-methyl alone had significantly lower RAUDPC values than other treatments, but were not different from each other.

Evaluation of application interval. At Fort Collins, the RAUDPC was reduced 14 and $9 \%$ by the biweekly and weekly bacteriophage intervals, respectively, as compared to the untreated (Table 5). Copper hydroxide-mancozeb and bacteriophages applied bimonthly were ineffective in reducing disease severity. At Rocky Ford, the RAUDPC was reduced by all treatments

Table 3. Effect of bacteriophages, acibenzolar-S-methyl, and copper hydroxide-mancozeb on the severity of Xanthomonas leaf blight of onion and bulb yield at Yuma and Rocky Ford, CO, 2003

\begin{tabular}{|c|c|c|c|c|c|}
\hline \multirow[b]{3}{*}{ Treatment $^{\mathrm{z}}$} & \multicolumn{5}{|c|}{ Location, disease severity (RAUDPC), and yield ${ }^{w, x, y}$} \\
\hline & \multirow{2}{*}{$\begin{array}{c}\text { Yuma } \\
\text { RAUDPC }\end{array}$} & \multicolumn{4}{|c|}{ Rocky Ford } \\
\hline & & RAUDPC & Medium & Jumbo & Total \\
\hline Untreated & $0.26 \mathrm{a}$ & $0.19 \mathrm{a}$ & $7.1 \mathrm{a}$ & $11.0 \mathrm{~b}$ & $18.9 \mathrm{a}$ \\
\hline Copper hydroxide-mancozeb & $0.18 \mathrm{~b}$ & $0.13 \mathrm{~b}$ & $6.1 \mathrm{ab}$ & $13.8 \mathrm{ab}$ & $21.2 \mathrm{a}$ \\
\hline Bacteriophages & $0.17 \mathrm{~b}$ & $0.14 \mathrm{~b}$ & $3.5 \mathrm{~b}$ & $14.1 \mathrm{ab}$ & $17.8 \mathrm{a}$ \\
\hline Bacteriophages + copper hydroxide-mancozeb & $0.18 \mathrm{~b}$ & $0.13 \mathrm{~b}$ & $4.6 \mathrm{ab}$ & $15.4 \mathrm{a}$ & $22.0 \mathrm{a}$ \\
\hline Bacteriophages + acibenzolar- $S$-methyl & $0.13 \mathrm{~b}$ & $0.11 \mathrm{~b}$ & $3.5 \mathrm{~b}$ & $15.1 \mathrm{a}$ & $19.3 \mathrm{a}$ \\
\hline $\mathrm{LSD}_{0.05}$ & 0.07 & 0.04 & 3.27 & 3.45 & 6.55 \\
\hline
\end{tabular}

${ }^{\mathrm{w}} \mathrm{RAUDPC}=$ relative area under the disease progress curve, calculated according to:

$\left\{\sum_{i=1}^{n}\left[\left(x_{i+1}+x_{i}\right) / 2\right]\left(t_{i+1}-t_{i}\right)\right\} /\left(t_{n}-t_{i}\right)$ where $x_{i}$ is disease severity at time $t_{i}$. Treatments within a column followed by the same letter are not significantly different based on Fisher's protected least significant difference $(\alpha=0.05)$. Data are means of 10 subsamples of four replicates $(n=4)$.

x Cultivar Vantage was used at Yuma and cultivar X-202 was used at Rocky Ford.

${ }^{y}$ Medium grade bulbs are those with a diameter of 5.1 to $8.3 \mathrm{~cm}$; jumbo grade bulbs are those with a diameter of 8.3 to $9.5 \mathrm{~cm}(31)$. Total yield (kg) is yield of all bulbs harvested from a 3-m section selected arbitrarily from each plot. Yield data were not collected at Yuma.

${ }^{\mathrm{z}}$ Five to 6 weekly applications of $1.55 \mathrm{~kg}$ a.i./ha copper hydroxide $+0.50 \mathrm{~kg}$ a.i./ha mancozeb; 10 to 12 biweekly applications of bacteriophages applied at $10^{8} \mathrm{pfu} / \mathrm{ml}$ in a stabilizing solution of water, $0.25 \%$ sucrose, $0.5 \%$ Casecrete NH-400 (American Casein Company, Burlington, NJ), and 0.5\% corn flour (3); 5 to 6 weekly bacteriophage and copper hydroxide-mancozeb applications at same rates as above; 10 to 12 biweekly bacteriophage applications, same rate as above, with two preventative acibenzolar- $S$-methyl applications at $26.3 \mathrm{~g}$ a.i./ha.

Table 4. Effect of bacteriophages, acibenzolar- $S$-methyl, and copper hydroxide-mancozeb on the severity of Xanthomonas leaf blight of onion and bulb yield at Fort Collins and Rocky Ford, CO, 2004

\begin{tabular}{|c|c|c|c|c|c|c|c|c|}
\hline \multirow[b]{3}{*}{ Treatment $^{\mathrm{z}}$} & \multicolumn{8}{|c|}{ Location, disease severity (RAUDPC), and yield ${ }^{w, x, y}$} \\
\hline & \multicolumn{4}{|c|}{ Fort Collins } & \multicolumn{4}{|c|}{ Rocky Ford } \\
\hline & RAUDPC & Medium & Jumbo & Total & RAUDPC & Medium & Jumbo & Total \\
\hline Untreated & $0.21 \mathrm{a}$ & $19.0 \mathrm{a}$ & $9.6 \mathrm{a}$ & $35.9 \mathrm{a}$ & $0.28 \mathrm{a}$ & $14.9 \mathrm{a}$ & $9.1 \mathrm{a}$ & $26.1 \mathrm{~b}$ \\
\hline Copper hydroxide-mancozeb & $0.18 \mathrm{~b}$ & $17.8 \mathrm{ab}$ & $7.0 \mathrm{a}$ & $30.9 \mathrm{a}$ & $0.23 \mathrm{~b}$ & $16.9 \mathrm{a}$ & $8.3 \mathrm{a}$ & $26.9 \mathrm{ab}$ \\
\hline Bacteriophages & $0.18 \mathrm{~b}$ & $13.3 \mathrm{~b}$ & $12.5 \mathrm{a}$ & $30.8 \mathrm{a}$ & $0.22 \mathrm{~b}$ & $16.6 \mathrm{a}$ & $9.0 \mathrm{a}$ & $27.1 \mathrm{ab}$ \\
\hline Bacteriophages + copper hydroxide-mancozeb & $0.18 \mathrm{~b}$ & $14.8 \mathrm{ab}$ & $13.9 \mathrm{a}$ & $33.0 \mathrm{a}$ & $0.19 \mathrm{c}$ & $16.8 \mathrm{a}$ & $8.9 \mathrm{a}$ & $30.4 \mathrm{a}$ \\
\hline Bacteriophages + acibenzolar- $S$-methyl & $0.16 \mathrm{c}$ & $17.6 \mathrm{ab}$ & $10.4 \mathrm{a}$ & $33.3 \mathrm{a}$ & $0.19 \mathrm{c}$ & $15.6 \mathrm{a}$ & $7.9 \mathrm{a}$ & $26.8 \mathrm{ab}$ \\
\hline Acibenzolar-S-methyl & $0.18 \mathrm{~b}$ & $19.1 \mathrm{a}$ & $10.4 \mathrm{a}$ & $36.9 \mathrm{a}$ & $0.18 \mathrm{c}$ & $15.0 \mathrm{a}$ & $10.8 \mathrm{a}$ & $28.4 \mathrm{ab}$ \\
\hline $\mathrm{LSD}_{0.05}$ & 0.01 & 4.86 & 7.15 & 6.32 & 0.03 & 4.05 & 6.15 & 3.68 \\
\hline
\end{tabular}

${ }^{\mathrm{w}}$ RAUDPC $=$ relative area under the disease progress curve, calculated according to:

$\left\{\sum_{i=1}^{n}\left[\left(x_{i+1}+x_{i}\right) / 2\right]\left(t_{i+1}-t_{i}\right)\right\} /\left(t_{n}-t_{i}\right)$ where $x_{i}$ is disease severity at time $t_{i}$. Treatments within a column followed by the same letter are not significantly

different based on Fisher's protected least significant difference $(\alpha=0.05)$. Data are means of 10 subsamples of four replicates $(n=4)$.

${ }^{x}$ Cultivar Vantage was used at Fort Collins and cultivar X-202 was used at Rocky Ford.

${ }^{y}$ Medium grade bulbs are those with a diameter of 5.1 to $8.3 \mathrm{~cm}$; jumbo grade bulbs are those with a diameter of 8.3 to $9.5 \mathrm{~cm}(31)$. Total yield (kg) is yield of all bulbs harvested from a 3-m (Fort Collins) or 2.4-m (Rocky Ford) section selected arbitrarily from each plot.

${ }^{\mathrm{z}}$ Eight to 10 weekly applications of $1.55 \mathrm{~kg}$ a.i./ha copper hydroxide $+0.50 \mathrm{~kg}$ a.i./ha mancozeb; 16 to 19 biweekly applications of bacteriophages applied at $10^{8} \mathrm{pfu} / \mathrm{ml}$ in a stabilizing solution of water, $0.25 \%$ sucrose, $0.5 \%$ Casecrete NH-400 (American Casein Company, Burlington, NJ), and $0.5 \%$ corn flour (3); 8 to 10 weekly bacteriophage and copper hydroxide-mancozeb applications at same rates as above; 16 to 19 biweekly bacteriophage applications, same rate as above with two preventative acibenzolar- $S$-methyl applications at $26.3 \mathrm{~g}$ a.i./ha; two preventative acibenzolar- $S$-methyl applications at $26.3 \mathrm{~g}$ a.i./ha. 
except the bimonthly bacteriophage interval, but those treatments were not different from each other. Copper hydroxidemancozeb, biweekly, and weekly bacteriophage applications reduced disease severity by 11,15 , and $11 \%$, respectively, compared to the untreated. Total yield was not improved by any treatment, but there was a trend in increased jumbo yield from plots treated with copper hydroxide-mancozeb or biweekly bacteriophages. The bacteriophage mixture applied weekly was as effective as copper hydroxide-mancozeb at reducing disease severity.

Evaluation of bacteriophage titer. At Fort Collins, the RAUDPC was reduced by all bacteriophage treatments compared to the untreated, but not by copper hydroxidemancozeb (Table 6). Bacteriophage treatments applied at $10^{8}, 10^{7}, 10^{6}$, and $10^{5}$ $\mathrm{pfu} / \mathrm{ml}$ reduced disease severity by 14,14 , 9 , and $14 \%$, respectively, compared to the untreated. Titers of $10^{8}, 10^{7}$, and $10^{5}$ $\mathrm{pfu} / \mathrm{ml}$ reduced disease severity compared to copper hydroxide-mancozeb, but disease severity among the titers was similar. Yield was not affected by any treatment at Fort Collins. At Rocky Ford, no treatment reduced disease significantly or improved bulb yield compared to the untreated plots.

\section{DISCUSSION}

Our data indicate that bacteriophage populations are not readily degraded in the onion phyllosphere over 4 or 5 days in the field or greenhouse in Colorado. The apparent stability of bacteriophage populations over this time period under both greenhouse and field conditions suggests it may be possible to lengthen the time interval between applications beyond this period without affecting efficacy; however, under field conditions, control was significantly better when bacteriophage applications were on a 3- to 4-day interval than on a 7-day or 14-day interval.
In field experiments, it was hypothesized that bacteriophage populations would decline initially, then increase as the bacteriophages colonized and replicated within $X$. axonopodis pv. allii host cells, and finally diminish over about 5 days. However, results were inconsistent with this hypothesis because in both studies populations survived on onion leaves much longer than expected. Experiment 2 bacteriophage populations were considerably lower than in experiment 1 , possibly due to fewer viable host cells as a result of increased necrotic tissue and less young, freshly infected tissue, or because the randomly selected tissue samples were not adequately covered with the original bacteriophage solution. Overall, these field experiments yielded somewhat variable results, but our original hypothesis was rejected.

In greenhouse studies, bacteriophage populations, without or with $X$. axonopodis

Table 5. Effect of varied bacteriophage application interval on the severity of Xanthomonas leaf blight of onion and bulb yield at Fort Collins and Rocky Ford, CO, 2004

\begin{tabular}{|c|c|c|c|c|c|c|c|c|}
\hline \multirow[b]{3}{*}{ Treatment ${ }^{\mathrm{z}} /$ interval } & \multicolumn{8}{|c|}{ Location, disease severity (RAUDPC), and yield ${ }^{\mathrm{w}, \mathrm{x}, \mathrm{y}}$} \\
\hline & \multicolumn{4}{|c|}{ Fort Collins } & \multicolumn{4}{|c|}{ Rocky Ford } \\
\hline & RAUDPC & Medium & Jumbo & Total & RAUDPC & Medium & Jumbo & Total \\
\hline Untreated & $0.22 \mathrm{a}$ & $19.0 \mathrm{a}$ & $16.1 \mathrm{a}$ & $35.3 \mathrm{a}$ & $0.27 \mathrm{a}$ & $15.5 \mathrm{ab}$ & $7.3 \mathrm{bc}$ & $25.9 \mathrm{a}$ \\
\hline Copper hydroxide-mancozeb & $0.21 \mathrm{a}$ & $14.4 \mathrm{a}$ & $13.1 \mathrm{a}$ & $30.5 \mathrm{a}$ & $0.24 \mathrm{bc}$ & $13.1 \mathrm{~b}$ & $12.3 \mathrm{a}$ & $25.9 \mathrm{a}$ \\
\hline 3 to 4 day interval & $0.19 \mathrm{c}$ & $17.1 \mathrm{a}$ & $13.0 \mathrm{a}$ & $34.0 \mathrm{a}$ & $0.23 \mathrm{c}$ & $15.6 \mathrm{ab}$ & $11.3 \mathrm{ab}$ & $27.3 \mathrm{a}$ \\
\hline 7-day interval & $0.20 \mathrm{~b}$ & $14.9 \mathrm{a}$ & $16.4 \mathrm{a}$ & $34.8 \mathrm{a}$ & $0.24 \mathrm{bc}$ & $17.4 \mathrm{a}$ & $6.1 \mathrm{c}$ & $26.0 \mathrm{a}$ \\
\hline 14-day interval & $0.2 \mathrm{ab}$ & $12.1 \mathrm{a}$ & 15.8 a & $30.5 \mathrm{a}$ & $0.26 \mathrm{ab}$ & $16.3 \mathrm{ab}$ & $9.1 \mathrm{abc}$ & $25.6 \mathrm{a}$ \\
\hline $\mathrm{LSD}_{0.05}$ & 0.01 & 7.78 & 10.34 & 10.46 & 0.03 & 3.86 & 4.61 & 3.98 \\
\hline
\end{tabular}

${ }^{\mathrm{w}}$ RAUDPC $=$ relative area under the disease progress curve, calculated according to:

$\left\{\sum_{i=1}^{n}\left[\left(x_{i+1}+x_{i}\right) / 2\right]\left(t_{i+1}-t_{i}\right)\right\} /\left(t_{n}-t_{i}\right)$ where $x_{i}$ is disease severity at time $t_{i}$. Treatments within a column followed by the same letter are not significantly

different based on Fisher's protected least significant difference $(\alpha=0.05)$. Data are means of 10 subsamples of four replicates $(n=4)$.

$x$ Cultivar Vantage was used at Fort Collins and cultivar X-202 was used at Rocky Ford.

${ }^{y}$ Medium grade bulbs are those with a diameter of 5.1 to $8.3 \mathrm{~cm}$; jumbo grade bulbs are those with a diameter of 8.3 to $9.5 \mathrm{~cm}(31)$. Total yield $(\mathrm{kg})$ is yield of all bulbs harvested from a 3-m (Fort Collins) or 2.4-m (Rocky Ford) section selected arbitrarily from each plot.

${ }^{\mathrm{z}} 16$ to 19 biweekly (3- to 4-day interval) applications of bacteriophages; 8 to 10 weekly (7-day interval) applications of bacteriophages; or 5 to 6 bimonthly (14-day interval) applications of bacteriophages. For comparison, 8 to 10 weekly applications of $1.55 \mathrm{~kg}$ a.i./ha copper hydroxide $+0.50 \mathrm{~kg}$ a.i./ha mancozeb were also included. All bacteriophage treatments were applied at $10^{8} \mathrm{pfu} / \mathrm{ml}$ in a stabilizing solution of water, $0.5 \%$ sucrose, and $0.75 \%$ powdered nonfat skim milk (3).

Table 6. Effect of varied bacteriophage titer on the severity of Xanthomonas leaf blight of onion and bulb yield at Fort Collins and Rocky Ford, CO, 2004

\begin{tabular}{|c|c|c|c|c|c|c|c|c|}
\hline \multirow[b]{3}{*}{ Treatment $^{\mathrm{z}}$} & \multicolumn{8}{|c|}{ Location, disease severity (RAUDPC), and yield ${ }^{\mathrm{w}, \mathrm{x}, \mathrm{y}}$} \\
\hline & \multicolumn{4}{|c|}{ Fort Collins } & \multicolumn{4}{|c|}{ Rocky Ford } \\
\hline & RAUDPC & Medium & Jumbo & Total & RAUDPC & Medium & Jumbo & Total \\
\hline Untreated & $0.22 \mathrm{a}$ & $20.0 \mathrm{a}$ & $10.0 \mathrm{a}$ & $33.5 \mathrm{a}$ & $0.26 \mathrm{a}$ & $15.5 \mathrm{a}$ & $10.6 \mathrm{ab}$ & $26.9 \mathrm{ab}$ \\
\hline Copper hydroxide-mancozeb & $0.21 \mathrm{ab}$ & $15.6 \mathrm{a}$ & $14.1 \mathrm{a}$ & $33.0 \mathrm{a}$ & $0.25 \mathrm{a}$ & $14.9 \mathrm{ab}$ & $11.6 \mathrm{a}$ & $27.6 \mathrm{a}$ \\
\hline $10^{8} \mathrm{pfu} / \mathrm{ml}$ & $0.19 \mathrm{c}$ & $15.1 \mathrm{a}$ & $11.3 \mathrm{a}$ & $29.1 \mathrm{a}$ & $0.24 \mathrm{a}$ & $17.1 \mathrm{a}$ & $6.1 \mathrm{c}$ & $24.4 \mathrm{~b}$ \\
\hline $10^{7} \mathrm{pfu} / \mathrm{ml}$ & $0.19 \mathrm{c}$ & $13.8 \mathrm{a}$ & $10.9 \mathrm{a}$ & $29.8 \mathrm{a}$ & $0.26 \mathrm{a}$ & $10.4 \mathrm{~b}$ & $11.6 \mathrm{a}$ & $25.8 \mathrm{ab}$ \\
\hline $10^{6} \mathrm{pfu} / \mathrm{ml}$ & $0.20 \mathrm{bc}$ & $18.9 \mathrm{a}$ & $10.4 \mathrm{a}$ & $33.6 \mathrm{a}$ & $0.26 \mathrm{a}$ & $17.9 \mathrm{a}$ & $7.5 \mathrm{bc}$ & $25.9 \mathrm{ab}$ \\
\hline $10^{5} \mathrm{pfu} / \mathrm{ml}$ & $0.19 \mathrm{c}$ & $18.0 \mathrm{a}$ & $12.7 \mathrm{a}$ & $35.5 \mathrm{a}$ & $0.25 \mathrm{a}$ & $16.1 \mathrm{a}$ & $7.0 \mathrm{bc}$ & $24.8 \mathrm{ab}$ \\
\hline $\mathrm{LSD}_{0.05}$ & 0.01 & 6.86 & 7.26 & 7.63 & 0.03 & 4.83 & 3.82 & 2.98 \\
\hline
\end{tabular}

${ }^{\mathrm{w}}$ RAUDPC $=$ relative area under the disease progress curve, calculated according to:

$\left\{\sum_{i=1}^{n}\left[\left(x_{i+1}+x_{i}\right) / 2\right]\left(t_{i+1}-t_{i}\right)\right\} /\left(t_{n}-t_{i}\right)$ where $x_{i}$ is disease severity at time $t_{i}$. Treatments within a column followed by the same letter are not significantly different based on Fisher's protected least significant difference $(\alpha=0.05)$. Data are means of 10 subsamples of four replicates $(n=4)$.

${ }^{x}$ Cultivar Vantage was used at Fort Collins and cultivar X-202 was used at Rocky Ford.

y Medium grade bulbs are those with a diameter of 5.1 to $8.3 \mathrm{~cm}$; jumbo grade bulbs are those with a diameter of 8.3 to $9.5 \mathrm{~cm}(31)$. Total yield $(\mathrm{kg})$ is yield of all bulbs harvested from a 3-m (Fort Collins) or 2.4-m (Rocky Ford) section selected arbitrarily from each plot.

${ }^{\mathrm{z}} 16$ to 19 biweekly applications of bacteriophages at these concentrations: $10^{8}, 10^{7}, 10^{6}$, and $10^{5} \mathrm{pfu} / \mathrm{ml}$. For comparison, 8 to 10 weekly applications of copper hydroxide-mancozeb at $1.55 \mathrm{~kg}$ a.i./ha copper hydroxide $+0.50 \mathrm{~kg}$ a.i./ha mancozeb were also included. All bacteriophage treatments were applied biweekly in a stabilizing solution of water, $0.5 \%$ sucrose, and $0.75 \%$ powdered nonfat skim milk (3). 
pv. allii, were maintained for 3 days before beginning to diminish. Environmental factors, such as humidity or temperature, or possibly solution runoff from spraying too high a volume of liquid inoculum and bacteriophage treatments in either location may have contributed to the bacteriophage degradation. In all three experiments, when plants were inoculated with $X$. axonopodis pv. allii, bacteriophage populations generally remained stable throughout the course of sampling, and no population increase occurred. Potentially, bacteriophage numbers are at equilibrium because infection and subsequent replication of the viruses replace those that are degraded. While bacteria are susceptible to bacteriophages, they also have many mechanisms to protect themselves from host defenses and environmental stress. Xanthomonads, for example, produce a thick extracellular polysaccharide (xanthan) that protects some cells from bacteriophage infection, which may have been the case in these studies (14). The upright morphology of onion foliage may also contribute to bacteriophages' ability to survive for extended periods of time compared to other plants such as tomato (3). Onion leaf architecture could provide protection from UV radiation or other environmental stresses because bacteriophages may be more protected near the whorl of the leaves.

Greater increases in bacteriophage populations may be more evident when a bacterial population has already become established. In the absence of $X$. axonopodis pv. allii, bacteriophage populations fluctuated more initially than those inoculated with $X$. axonopodis pv. allii and then stabilized over time. This is interesting because without any host cells for bacteriophages to replicate in, it was hypothesized that populations would rapidly decline. The stabilizing solutions used for application of the bacteriophages may have provided protection from environmental factors.

Over time and locations, bacteriophage treatments reduced Xanthomonas leaf blight severity and provided disease suppression equal or superior to the conventional copper hydroxide-mancozeb treatment under field conditions. However, the bacteriophage treatments had no effect on yield because of excessive disease pressure or, possibly, inadequate disease control by any treatment tested. Gent and Schwartz (11) established that four weekly applications of acibenzolar- $S$-methyl reduce disease severity as or more effectively than a standard copper hydroxide-mancozeb program, and these results revealed in 2004 that a biweekly application of bacteriophages and preventative acibenzolar- $S$ methyl treatment were also the most effective at reducing disease severity. A 14-day interval of the bacteriophage mixture was not an effective treatment, but for convenience and efficiency, the 7-day interval may be a good alternative because it was equally effective as copper hydroxidemancozeb at reducing disease severity.

These results suggest that integration of bacteriophages and acibenzolar- $S$-methyl may be a viable alternative to conventional copper bactericides for management of Xanthomonas leaf blight, consistent with previous reports (11). Further field experiments involving bacteriophages in other onion growing regions are needed for verification of efficacy and to determine if yield improvement is possible. There were unexpected results from the field titer studies, and at Rocky Ford there was not a significant reduction in disease, possibly due to the more intense disease pressure at this location. Implementing the use of bacteriophages for biological control of Xanthomonas leaf blight should also be validated in other onion growing regions where different populations of $X$. axonopodis pv. allii may be present. A bacteriophage biological control program likely would be most useful in preventative management of Xanthomonas leaf blight of onion, if bacteriophages can establish on plant tissue prior to disease development. A clear advantage to using this system is the development of field-specific bacteriophage mixtures to efficiently accommodate the local resident pathogen population.

Analysis of estimated product cost, excluding cost to make applications, reveals that the alternative management programs are not currently as affordable as the conventional program, which also protects onion against other diseases. Ten weekly applications of conventional copper hydroxide and mancozeb cost approximately $\$ 250 /$ ha. Based on Agriphage prices for tomato bacterial disease management, a weekly or biweekly bacteriophage mixture application would cost two to three times more than the conventional program, respectively, per season. Further research and increased market share may allow for reduction in the cost of bacteriophage mixtures for plant disease management. In these studies, acibenzolar- $S$-methyl applied alone or in combination with a bacteriophage program was a useful disease management tool. Preventative applications of acibenzolar- $S$-methyl two to four times a season (11) would cost about $20 \%$ less than the bacteriophage program or over $50 \%$ more than a conventional copper hydroxide-mancozeb program, respectively. Additional cost benefits from acibenzolar-S-methyl that cannot be quantified may include protection or reduction in severity from other diseases. At the time of these studies, acibenzolar- $S$-methyl was registered for use on onions to manage Iris yellow spot virus, and some Colorado growers were already using this product.

If growers adopt alternative management strategies now, they may reduce their costs in the future because they would avoid a buildup of copper-tolerant strains and/or future restrictions governing the use of EBDC fungicides. Biological control and plant defense stimulators are more sustainable than copper hydroxide and mancozeb products because they readily degrade in the ecosystem, may delay development of tolerant strains, and do not leave potentially harmful residues on the plants. These materials are safer to handle by applicators as well.

Future studies should evaluate tankmixing bacteriophages with multiple applications of acibenzolar- $S$-methyl to improve disease management and yield. Similarly, a greater mixture of bacteriophages with host ranges for multiple bacterial pathogens could compose marketable and broad-spectrum products warranting future investigation. An integrated management approach utilizing crop rotation, sanitation, disease forecasting, and a resistant or less susceptible cultivar(s) plus biological control with bacteriophages and acibenzolar- $S$-methyl has excellent potential as an alternative to a conventional copper bactericide-EBDC fungicide program.

\section{ACKNOWLEDGMENTS}

Financial support was provided by the Colorado Onion Association and USDA/CSREES Crops at Risk Grant No. 2002-51100-01905, entitled "Integrated Management of Xanthomonas Leaf Blight of Onion by Cultural Practices, Disease Forecasting, and Biologically-Based Pesticides." We thank Erin Frank, Kristen Otto, and Mike Bartolo for excellent technical support and cooperation. We also thank Mike Bartolo and Jan Leach for reviewing the manuscript.

\section{LITERATURE CITED}

1. Alvarez, A. M., Buddenhagen, I. W., Buddenhagen, E. S., and Domen, H. Y. 1978. Bacterial blight on onion, a new disease caused by Xanthomonas sp. Phytopathology 68:1132-1136.

2. Anith, K. N., Momol, M. T., Kloepper, J. W., Marois, J. J., Olson, S. M., and Jones, J. B. 2004. Efficacy of plant growth-promoting rhizobacteria, acibenzolar- $S$-methyl, and soil amendment for integrated management of bacterial wilt of tomato. Plant Dis. 88:669-673.

3. Balogh, B., Jones, J. B., Momol, M. T., Olson, S. M., Obradovic, A., King, P., and Jackson, L. E. 2003. Improved efficacy of newly formulated bacteriophages for management of bacterial spot on tomato. Plant Dis. 87:949-954.

4. Bender, C. L., and Cooksey, D. A. 1986. Indigenous plasmids in Pseudomonas syringae pv. tomato: Conjugative transfer and role in copper resistance. J. Bacteriol. 165:534-541.

5. Cole, D. L. 1999. The efficacy of acibenzolarS-methyl, an inducer of systemic acquired resistance, against bacterial and fungal diseases of tobacco. Crop Prot. 94:S34.

6. Flaherty, J. E., Harbaugh, B. K., Jones, J. B., Somodi, G. C., and Jackson, L. E. 2001. Hmutant bacteriophages as a potential biocontrol of bacterial blight of geranium. HortScience 36:98-100.

7. Flaherty, J. E., Jones, J. B., Harbaugh, B. K., Somodi, G. C., and Jackson, L. E. 2000. Control of bacterial spot on tomato in the greenhouse and field with $\mathrm{H}$-mutant bacteriophages. HortScience 35:882-884.

8. Gent, D. H., Lang, J. M., Bartolo, M. E., and Schwartz, H. F. 2005. Inoculum sources and survival of Xanthomonas axonopodis pv. allii in Colorado. Plant Dis. 89:507-514.

9. Gent, D. H., Lang, J. M., and Schwartz, H. F. 
2005. Epiphytic survival of Xanthomonas axonopodis pv. allii and $X$. axonopodis $\mathrm{pv}$. phaseoli on leguminous hosts and onion. Plant Dis. 89:558-564.

10. Gent, D. H., and Schwartz, H. F. 2005. Effect of nitrogen fertilization and seed contamination on epiphytic populations of Xanthomonas axonopodis pv. allii and development of Xanthomonas leaf blight of onion. Plant Health Progress doi:10.1094/PHP-2005-03XX-01-RS.

11. Gent, D. H., and Schwartz, H. F. 2005. Management of Xanthomonas leaf blight of onion with a plant activator, biological control agents, and copper bactericides. Plant Dis. 89:631-639.

12. Gent, D. H., Schwartz, H. F., Ishimaru, C. A., Louws, F. J., Cramer, R. A., and Lawrence, C. B. 2004. Polyphasic characterization of Xanthomonas strains from onion. Phytopathology 94:184-195.

13. Goodridge, L. D. 2004. Bacteriophage biocontrol of plant pathogens: Fact or fiction? Trends Biotechnol. 22:384-385.

14. Goto, M. 1992. Fundamentals of Bacterial Plant Pathology. Academic Press, Inc., San Diego, CA.

15. Horsfall, J. G., and Barratt, R. W. 1945. An improved grading system for measuring diseases. Phytopathology 35:665.

16. Houeto, P., Bindoula, G., and Hoffman, J. R. 1995. Ethylene-bisdithiocarbamates and ethylenethiourea: Possible human health hazards. Environ. Health Perspect. 103:568-573.

17. Isakeit, T., Miller, M. E., Barnes, L. W., Dickstein, E. R., and Jones, J. B. 2000. First report of leaf blight of onion caused by Xanthomonas campestris in the continental United States. Plant Dis. 84:201.

18. Jackson, L. E. 1989. Bacteriophage prevention and control of harmful plant bacteria. US Patent, Patent No. 4,828,999.

19. Kadota, I., Uehara, K., Shinohara, H., and
Nishiyama, K. 2000. Bacterial blight of Welsh onion: A new disease caused by Xanthomonas campestris pv. allii pv. nov. J. Gen. Plant Pathol. 66:310-315.

20. Klement, Z. 1959. Some new specific bacteriophages for plant pathogenic Xanthomonas spp. Nature 184:1248-1249.

21. Louws, F. J., Wilson, M., Campbell, H. L., Cuppels, D. A., Jones, J. B., Shoemaker, P. B., Sahin, F., and Miller, S. A. 2001. Field control of bacterial spot and bacterial speck of tomato using a plant activator. Plant Dis. 85:481-488.

22. Nunez, J. J., Gilbertson, R. L., Meng, X., and Davis, R. M. 2002. First report of Xanthomonas leaf blight of onion in California. Plant Dis. 86:330.

23. Obradovic, A., Jones, J. B., Momol, M. T., Balogh, B., and Olson, S. M. 2004. Management of tomato bacterial spot in the field by foliar applications of bacteriophages and SAR inducers. Plant Dis. 88:736-740.

24. O'Garro, L. W., and Paulraj, L. P. 1997. Onion leaf blight caused by Xanthomonas campestris: Alternative hosts and resistant onion genotypes. Plant Dis. 81:978-982.

25. Paulraj, L., and O'Garro, L. W. 1992. Aspects of the epidemiology of a leaf blight of onion in Barbados. Pages 89-96 in: Proc. Annu. Conf. Barbados Soc. Technol. Agric. 10th, St. Micheal, Barbados.

26. Paulraj, L., and O'Garro, L. W. 1993. Leaf blight of onions in Barbados caused by Xanthomonas campestris. Plant Dis. 77:198-201.

27. Roumagnac, P., Gagnevin, L., Gardan, L., Sutra, L., Manceau, C., Dickstein, E. R., Jones, J. B., Rott, P., and Pruvost, O. 2004. Polyphasic characterization of xanthomonads isolated from onion, garlic and Welsh onion (Allium spp.) and their relatedness to different Xanthomonas species. Int. J. Syst. Evol. Microbiol. $54: 15-24$
28. Roumagnac, P., Gagnevin, L., and Pruvost, O. 2000. Detection of Xanthomonas sp., the causal agent of onion bacterial blight, in onion seeds using a newly developed semi-selective medium. Eur. J. Plant Pathol. 106:867-877.

29. Roumagnac, P., Pruvost, O., Chiroleu, F., and Hughes, G. 2004. Spatial and temporal analyses of bacterial blight of onion caused by Xanthomonas axonopodis pv. allii. Phytopathology 94:138-146.

30. Sanders, F. H., Langston, D. B., Jr., Brock, J. H., and Gitaitis, R. D. 2003. First report of a leaf blight of onion caused by Xanthomonas spp. in Georgia. Plant Dis. 87:749.

31. Schwartz, H. F., and Bartolo, M. E., eds. 1995 Colorado onion production and integrated pest management. Reg. Bull. No. 562A. Colorado State University, Fort Collins.

32. Schwartz, H. F., and Otto, K. 2000. First report of leaf blight of onion by Xanthomonas campestris in Colorado. Plant Dis. 84:922.

33. Schwartz, H. F., and Otto, K. J. 1998. Onion bacterial disease management in Colorado. Pages 214-218 in: Proc. 1998 Nat. Onion (and other Allium) Res. Conf., Sacramento, CA

34. Schwartz, H. F. Otto, K. L., and Gent, D. H. 2003. Relation of temperature and rainfall to development of Xanthomonas and Pantoea leaf blights of onion in Colorado. Plant Dis. 87:1114.

35. Serfontein, J. J. 2001. Xanthomonas blight of onion in South Africa. Plant Dis. 85:442.

36. Stall, R. E., Loschke, D. C., and Jones, J. B. 1986. Linkage of copper resistance and avirulence loci on a self-transmissible plasmid in Xanthmonas campestris pv. vesicatoria. Phytopathology 76:240-243.

37. Weller, D. M., and Saettler, A. W. 1978. Rifampin-resistant Xanthomonas phaseoli var. fuscans and Xanthomonas phaseoli: Tools for field study of bean blight bacteria. Phytopathology 68:778-781. 